УДК 311.21:331.5

Пономаренко I.B.

канд. економ. наук, дочент

ДННУ «Академія фінансового управління»

Віннікова I.I.

канд. економ. наук, дочент

ДВНЗ «Київський начіональний економічний університет імені Вадима Гетьмана»

Гребньов Г.М.

Національний технічний університет України «КПІ»

\title{
ОСОБЛИВОСТІ ФУНКЦІОНУВАННЯ РИНКУ ПРАЦ УКРАЇНІ В УМОВАХ ІНТЕГРАЦІЇ ДО ЄВРОПЕЙСЬКОГО СОЮЗУ
}

\section{ОСОБЕННОСТИ ФУНКЦИОНИРОВАНИЯ РЫНКА ТРУДА УКРАИНЫ В УСЛОВИЯХ ИНТЕГАЦИИ В ЕВРОПЕЙСКИЙ СОЮЗ}

\section{FEATURES OF UKRAINE LABOUR MARKET FUNCTIONING IN THE CONDITIONS OF INTEGRATION IN THE EUROPEAN UNION}

У статті проведено порівняльний аналіз стану ринку праці України та країн $Є С$ в сучасних умовах за основними показниками. Обгрунтовано дочільність співставлення ринків праці країн ЄС та Украӥни. Окреслено негативний вплив тимчасової окупації Криму, військових дій на території Донецької $і$ Луганської областей, а також кризових явищ в украӥнській економіці на національний ринок прачі. Застосовано систему статистичних показників економічної активності населення (зайнятих та безробітних), обчислених за допомогою методології Міжнародної організації праці. Показано взаємоємозв'язок між ступенем розвитку соціально-трудових відносин та рівнем оплати праці економічно активного населення. Обтрунтовано дочільність проведення порівняльного аналізу в Украӥні та краӥнах Свропейського союзу за допомогою показника «мінімальна заробітна плата». Використано методику рейтингового очінювання країн за основними показниками ринку прачі з подальшим визначенням країн $С С$, ринки пращі яких подібні до українського. Доведено, щзо зазначений підхід дозволить визначити механізми регулювання зайнятості населення в Украӥні шляхом подолання структурних та територіальних диспропориій.

Ключові слова: ринок праці, економічна активність населення, зайнятість та безробіття, рейтингова оцінка.

В статье проведен сравнительный анализ состояния рынка труда Украины и стран EC в современных условиях по основныл показателям. Обоснована целесообразность сопоставления рынков труда стран ЕС и Украины. Определено негативное влияние временной оккупации Крыма, военных действий на территории Донецкой и Луганской областей, а также кризисных явлений в украинской экономике на национальный рынок труда. Применена система статистических показателей экономической активности населения (занятых и безработных), вычисленных $c$ помощью методологии Международной организации труда. Показана взаимосвязь между степенью развития 
сочиально-трудовых отношений и уровнем оплаты труда экономически активного населения. Обоснована целесообразность проведения сравнительного анализа в Украине и странах Европейского союза с помощью показателя «минимальная заработная плата». Использована методика рейтинговой оценки стран по основным показателям рынка труда с дальнейшим определением стран ЕС, рынки труда которых подобны украинскому. Доказано, что указанный подход позволит определить механизмы регулирования занятости населения в Украине путем преодоления структурных и территориальных диспропоричй.

Ключевые слова: рынок труда, экономическая активность населения, занятость и безработица, рейтинговая оценка.

This article provides a comparative analysis of the labor market in Ukraine and the EU in the current conditions for the major indexes. Expediency comparison of labor markets of the EU and Ukraine are grounded. Outlined the negative impact of temporary occupation of the Crimea, hostilities in the Donetsk and Lugansk regions, as well as the crisis in the Ukrainian economy to the national labor market. Applied system of statistical indicators of economic activity (employed and unemployed), calculated using the methodology of the International Labour Organisation. The correlation between the degree of social and labor relations and wages of the economically active population are showed. Expediency comparative analysis in Ukraine and the European Union by means of indicator "minimum wage" are grounded. Used methodologies of evaluation of the main indicators of the labor market with further definition of EU labor markets which are similar to Ukrainian. It is proved that this approach will determine the mechanisms of regulation of employment in Ukraine by overcoming structural and regional imbalances.

Key words: labor market, population, economic activity, employment and unemployment, rating.

Вступ. Реформування економіки України в умовах зміни вектору економічного співробітництва та активізації інтеграції до європейського економічного простору повязане 3 вирішення стратегічних завдань стосовно підвищення рівня конкурентоспроможності національного виробника, прискорення темпів економічного зростання тощо. Але поряд 3 цим виникає низка проблем, які потребують вирішення на перехідному етапі, насамперед мінімізацію негативних явищ, які позначаються на економічній активності населення.

Вплив глобалізації на українську економіку характеризується підвищенням конкуренції внаслідок лібералізації протекціоністської політики уряду щодо національного виробника та входження на ринок іноземних компаній. Відбуваються певні структурні зміни в економіці: зміна питомої ваги різних видів економічної діяльності у ВВП; перерозподіл ринків між національними та іноземними товаровиробниками, які, у тому числі, призводять до припинення економічної діяльності неконкурентноздатних підприємств, зменшення оплати праці у деяких секторах економіки та збільшення чисельності вивільнених працівників. Перед країною постає проблема адаптації, як економіки в цілому, так і національного ринку праці, 
зокрема, до міжнародних стандартів. Досягнення поставленої мети потребує дослідження функціонування ринку праці в країні та проведення порівняльного аналізу основних показників в Україні з іншими державами.

Представлені аспекти дослідження зайнятості населення знайшли відображення в роботах вітчизняних науковців: З.П. Бараник, С.I. Бандура, Д.П. Богині, В.Я. Брича, В.С. Васильченка, 3.С. Варналія, І.Ф. Гнібіденка, М.І. Долішнього, Т.А. Заяць, С.М. Злупка, Е.М. Лібанової, Л.С. Лісогор, В.В. Онікієнка, Н.О. Парфенцевої, В.М. Петюха, С.І. Пірожкова, В.Г. Саріогло, Т.О. Стеценко та ін.

Подальше дослідження ринку праці доцільно проводити у зв'язку 3 потребами оцінки ефективності використання наявних людських ресурсів. Поряд 3 цим важливо приділяти значну вагу соціальному захисту економічно активного населення, в першу чергу, гідному рівню оплати. Для України орієнтиром щодо розвитку ринку праці можуть слугувати країни СС.

Постановка завдання. Метої статті $\epsilon$ проведення комлексного статистичного дослідження економічно активного населення в Україні, а також його основних складових - зайнятих та безробітних. Аналіз якісних та кількісних показників економічної активності за різними соціальнодемографічними ознаками дозволить порівняти рівень розвитку України 3 країнами Європейського Союзу, а також оцінити перспективи розвитку та сформувати систему управлінських рішень щодо покращення зайнятості населення в українській державі.

Методологія. При дослідженні використовувалися такі статистичні методи: варіації, рейтингової оцінки, графічний, табличний. Зазначені методи дали можливість проаналізувати ситуацію із зайнятістю населення в України та провести порівняльний аналіз з країнами СС. У роботі розрахунки виконано за допомогою Microsoft Office Excel.

Результати дослідження. Еволяція ринку в Україні потребує постійного дослідження, порівняння тенденцій його розитку з передовими країнами світу, що передбачає співроітництво міжнародними організаціями. Так, у вересні 2015 р. в країні завершила роботу спільна оглядова місія Програми розвитку ООН (ПРООН) та Міжнародної організації праці (МОП) з питань зайнятості, яка працювала на запит Міністерства соціальної політики та Державної служби зайнятості. Отримані результати будуть використані при розробці стратегії ООН стосовно сприяння зайнятості в Україні 3 урахуванням європейських підходів. Вдосконалення зазначених підходів передбачає періодичне дослідження ринку праці України у порівнянні 3 країнами ЄС. Статистичний аналіз вітчизняного ринку праці доцільно проводити у декілька етапів. 
На першому етапі дослідження необхідно проаналізувати економічну активність населення. При проведенні порівняльного аналізу використано статистичну інформацію, яка була отримана згідно 3 рекомендаціями Міжнародної Організації Праці (МОП) та 13-ої Міжнародної конференції статистиків праці від 29 жовтня 1982 р., поряд з цим були враховані національні особливості нормативно-правової бази. В Україні основним джерелом статистичної інформації про економічну активність населення $\epsilon$ вибіркові обстеження, які проводяться Державною службою статистики України. Представлений підхід дозволяє здійснити науково обгрунтованих співставлень функціонування трудового потенціалу в Україні та країнах СС. Слід зазначити, що основні показники ринку праці в Україні порівнюються впродовж 3 кварталу 2013 р. - 3 кварталу 2015 р., що пояснюється політичними подіями в країні, які призвели до тимчасової окупації АР Крим, військових подій в Доецькій і Луганській областях та економічної кризи.

Дослідження ринку праці показує, що протягом 3 кварталу 2013 р. - 3 кварталу 2015 р. чисельність економічно активного населення в Україні скоротилась на 2,8 млн. осіб або на 13,3\%. Рівень економічної активності населення віком 15-70 років у цілому в Україні за зазначений період часу зменшився 3 65,2\% до 62,5\%. В Україні спостерігається чітка тенденція до зменшення загальної чисельності економічно активного населення, 3 поступовим постарінням його. Ці негативні явища на ринку праці підтверджують загальні процеси депопуляції населення, що проходять в країні протягом останніх 24 років. Від‘ємне відтворення економічно активного населення призводить до погіршення ситуації з використанням трудового потенціалу країни.

Впродовж 3 кварталу 2013 р. - 3 кварталу 2015 р.середній рівень економічної активності населення у віці 15-64 років в СС (28 країн) зріс 3 $72,2 \%$ до $72,7 \%$. Наявні тенденції пояснюються впливом економічної ситуації на ринки праці країн Свропи.

В Законі Україні «Про забезпечення рівня прав та можливостей жінок і чоловіків» № 2866-15 від 08.09.2005 р. по відношенню до праці та одержання винагороди за неї висвітлені положення гендерної рівності, які представляють собою процес справедливого відношення до жінок і чоловіків [1]. Для забезпечення справедливості, особливо на ринку праці, повинні бути виключеними прояви будь-якої дискримінації у сфері праці по відношенню до жінок. 3 метою дослідження стану гендерної рівності необхідне здійснення порівняльного аналізу економічної активності чоловіків і жінок в Україні та країнах $\mathrm{CC}$ (рис. 1). 


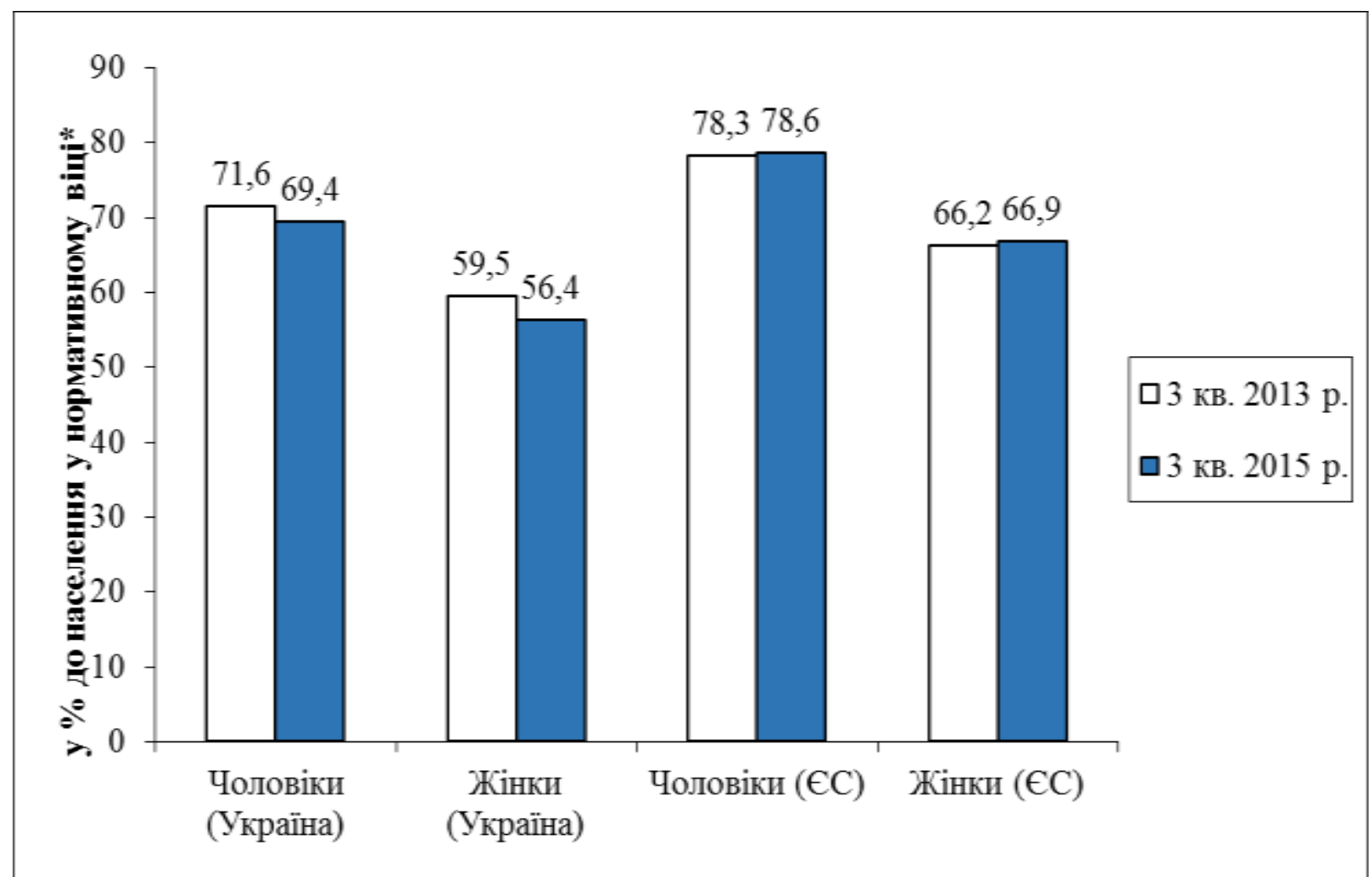

Рис. 1. Рівень економічної активності населення за статтю в Україні та країнах ЄС за 3 квартал 2013 р. - 3 квартал 2015 р.. [Побудовано за: 2, 3]

Дослідження якісного показника, рівня економічної активності, показало, що в країнах $Є С$ середній рівень економічної активності у чоловіків становив 78,3\% у 3 кварталі 2013 р. та 78,6\% у 3 кварталі 2015 р., а у жінок - 66,2\% та 66,9\% відповідно. В Україні у 3 кварталі 2013 р. значення досліджуваного показника у чоловіків становило 71,6\%, а у 3 кварталі 2015 р. - 69,4\%. Поряд 3 цим, рівень економічної активності у жінок був меншим ніж у чоловіків на 12,1 в.П. у 3 кварталі 2013 р. та на 13,0 в.п. у 3 кварталі 2015 р.

Порівняльний аналіз показує, що впродовж досліджуваного періоду рівень економічної активності в Україні порівняно з країнами СС був менше як у цілому, так і за статю. Поряд з цим в Україні спостерігається більш значна диференціація між рівнями економічної активності чоловіків та жінок, ніж у країнах Європи, тобто наявна гендерна незбалансованість, що свідчить про дискримінацію жінок на ринку праці.

Згідно з методологією Міжнародної Організації Праці економічно активне населення складається 3 двох основних категорій населення зайнятих та безробітних. Проведення порівняльного аналізу за даними

\footnotetext{
* Згідно з методологічними положеннями, на сайті Євростату розміщено статистичні дані по країнах $€ C$, які базуються на дослідженні економічної активності населення у віці 15-64 роки, а в Україні - населення у віці 15-70 років.
} 
категоріями дозволить більш розгорнуто проаналізувати наявні тенденції як на ринку праці України, так і країн СС.

Рівень зайнятості населення віком 15-70 років в Україні зменшився 3 $60,6 \%$ у 3 кварталі 2013 р. до 56,9\% у 3 кварталі 2015 р. Поряд 3 цим, у країнах $\mathrm{CC}$ середній рівень зайнятості населення зріс з 70,0\% у 3 кварталі 2013 р. до 71,5\% у 3 кварталі 2015 р. У 3 кварталі 2015 р. в Україні рівень зайнятості був вище ніж у Греції та Італії, в решті країн $Є С$ значення досліджуваного показника було вище (рис. 2).

Слід зауважити, що в країнах СС після економічної кризи 2008 р. спостерігаються відносно незначні коливання рівня зайнятості населення. Необхідно підкреслити важливу обставину, що основним фактором, який забезпечив стабільність розвитку ринків праці в регіоні, $\epsilon$ зростання продуктивності праці у нерозривному зв'язку з одночасним розвитком малих та середніх підприємств. Внаслідок даної комбінації рівень зайнятості у цілому в країнах $Є С$ зазнав зростання. Впродовж 3 кварталу 2013 - 3 кварталу 2015 р. рівень зайнятості найбільше зріс в Угорщині (на 5,9 в.п), Естонії (на 5,2 в.п.) та Мальті (на 3,8 в.п.). Проте, за досліджуваний період часу в чотирьох країнах відбулось зменшення значення даного показника (Бельгія на 0,2 в.п.; Австрія - 0,3 в.п.; Люксембург - 0,5 в.п.; Франція - 0,5 в.п.).

В умовах ринкової економіки для ринку праці характерним $є$ безробіття, яке поряд 3 негативними наслідками, також призводить до позитивних зрушень в економіці, за умови природного рівня даного показника, який згідно з положеннями економічної теорії становить 3-5\%.

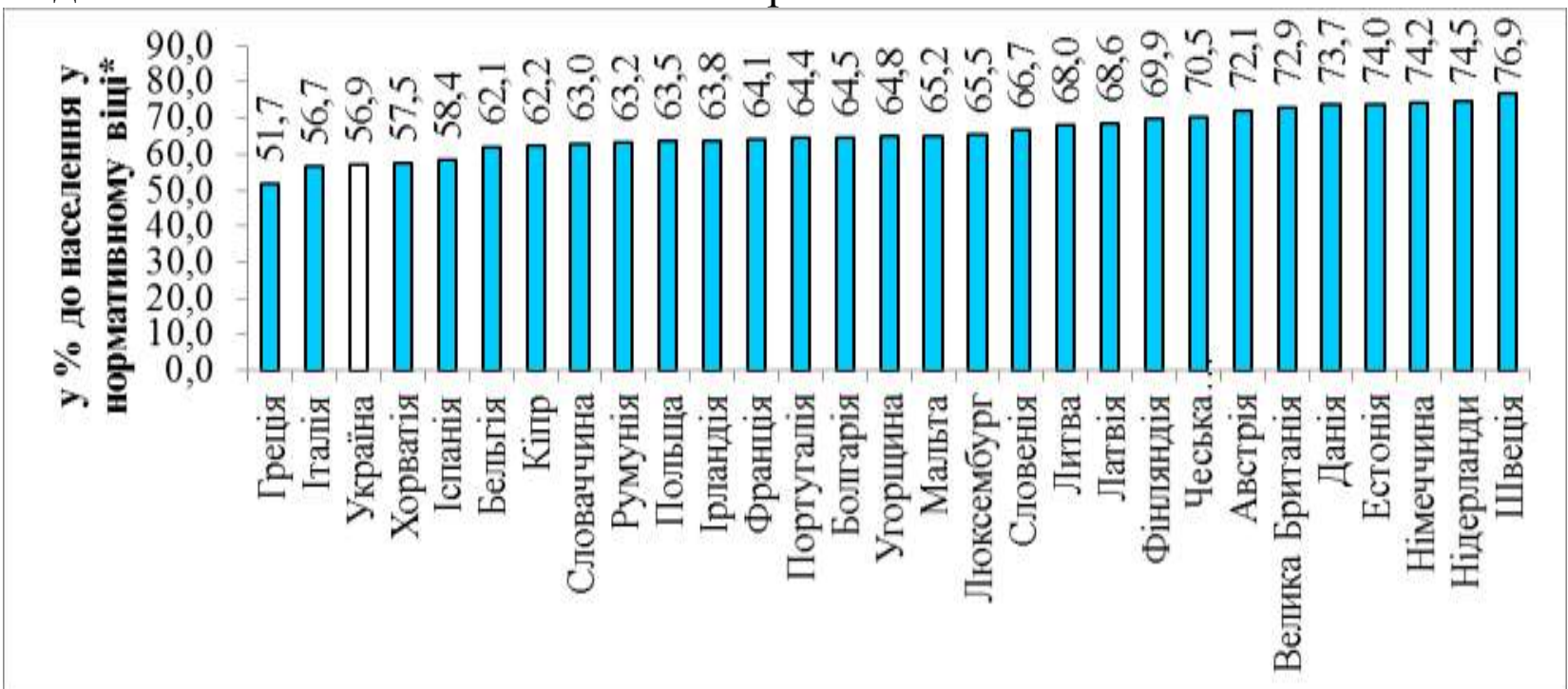

Рис. 2. Рівень зайнятості населення в Україні та країнах СС у 3 кварталі 2015 р. [Побудовано за: 2, 3]

У зв'язку з постійними структурними змінами в економіці виникає необхідність у перерозподілі робочої сили за видам економічної діяльності. Індикатором розвитку ринку праці також може слугувати питома вага 
працівників, які змінюють місце роботи у межах однієї професії у зв'язку з бажанням працювати в більш привабливих умовах. Внаслідок зазначених факторів відбувається рух робочої сили і певна частина економічно активного населення стає безробітною. В даних умовах безробіття, яке не перевищує природний рівень, є позитивним фактором розвитку як ринку праці, так i економіки в цілому. Тому, основою метою у сфері регулювання зайнятості $\epsilon$ створення умов щодо наближення чисельності безробітних до природного рівня через адміністративні та ринкові механізми $[4,5]$.

Рівень безробіття за методологією МОП в Україні з зріс з 7,1\% у 3 кварталі 2013 р. до 9,0\% у 3 кварталі 2015 р. Впродовж досліджуваного періоду середній рівень безробіття в СС зменшився з 10,5\% до 9,0\%.

Порівняльний аналіз ринку праці України з країнами Євросоюзу свідчить про відносне наближення рівня розвитку трудових відносин у нашій країні до міжнародних стандартів (рівень безробіття в 3 кварталі 2015 р. в Україні $7,2 \%$, максимальне значення даного показника спостерігається в Греції $24,1 \%$, а найменше - в Німеччині - 4,4\%). У вісімнадцяти країнах $\mathrm{CC}$ значення рівня безробіття менше, ніж в Україні. Отримані результати свідчать про необхідність вдосконалення державної політики сприяння зайнятості населення в Україні.

Дослідження інтенсивності динаміки рівня безробіття за методологією МОП показало, що впродовж 3 кварталу 2013 р. - 3 кварталу 2015 р. найбільше скоротилось значення даного показника в Іспанії (на 4,5 в.п.), а найбільше зросло - в Люксембурзі (на 2,1 в.п.). На рисунку 3 представлено зміну рівня безробіття населення за методологією МОП в Україні та країнах СС упродовж 3 кварталу 2013 р. - 3 кварталу 2015 p.

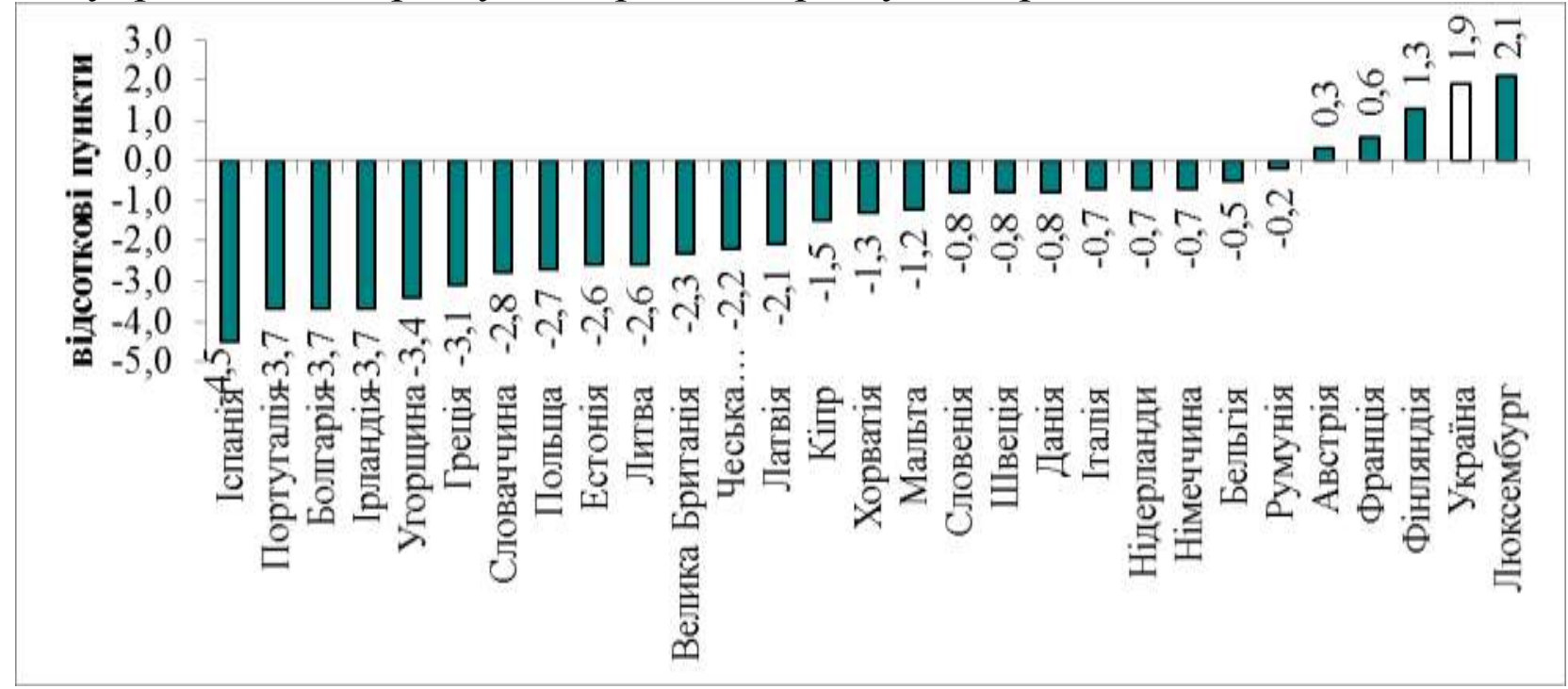

Рис. 3. Зміна рівня безробіття населення за методологісю МОП в Україні та країнах СС за 3 квартал 2013 р. - 3 квартал 2015 р. [Побудовано за: 2, 3] 
Даний статистичний підхід до дослідження економічної активності населення сприятиме розробці конкретних заходів щодо регулювання процесу зайнятості в країні, особливо в контексті визначення реальної ситуації стосовно чисельності основних категорій населення на ринку праці та оцінки їх рівня, трансформації соціально-економічних відносин на ринках праці, постійному удосконаленню законодавчої бази, спрямованої на підвищення рівня зайнятості населення.

Другий етап дослідження передбачає необхідність аналізу ситуації 3 оплатою праці. У зв'язку з військовими діями в Донецькій і Луганській областях та економічною кризою в Україні, спостерігається спад виробництва у промисловості, сільському господарстві та інших видах економічної діяльності, що у значній мірі призвело до відчутного зниження життєвого рівня населення. У зазначених умовах тема заробітної плати, розуміння іiі сутності та функцій стає надзвичайно актуальною, оскільки виникають складні проблеми у забезпеченні національних стандартів рівня життя населення окремих регіонів, у подоланні бідності та становленні середнього класу в країні.

Поряд 3 цим порівняльний аналіз рівня оплати праці в Україні та країнах СС дозволить оцінити національні стандарти в заробітній платі з стандартами, які використовуються в розвинених державах Свропи.

Одним з індикаторів рівня оплати праці в країні виступає мінімальна заробітна плата, рівень якої в Україні надзвичайно низький. При цьому в порівнянні з Болгарією, що знаходиться на останньому місці в СС за розміром мінімальної оплати праці, в Україні величина заробітної плати у 2015 р. була меншою в 3,7 рази. В той же час, найбільше співвідношення між мінімальною заробітною платою в Україні та в Люксембурзі становить 39,2 рази, тобто до пріоритетних напрямів України слід віднести удосконалення політики підвищення оплати праці.

Слід зауважити, що на сайті Євростату відсутні дані про досліджуваний показник по деяких країнах $\mathrm{CC}$, що пояснюється особливостями законодавства, збору та обробки статистичної інформації про ринок праці в цих державах. На рисунку 4 представлено мінімальну заробітну плату в Україні та 22 країнах СС за 2015 р. 


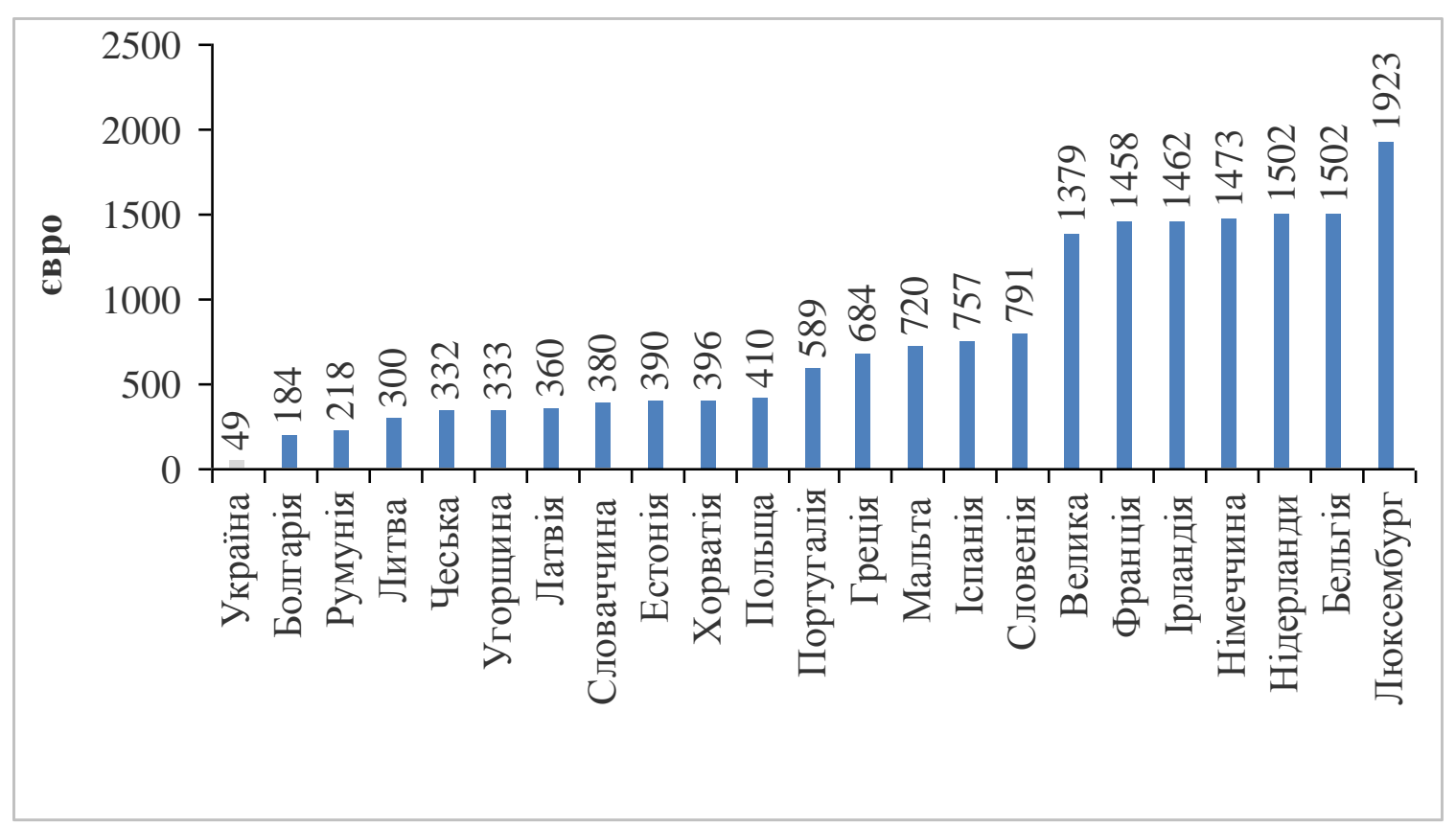

Рис. 4. Мінімальна заробітна плата в Україні та країнах ЄС за 2015

\section{р. [Побудовано за: 2, 3]}

Розмір мінімальної заробітної плати має поступово підвищуватись до рівня прожиткового мінімуму 3 урахуванням економічних показників розвитку національної економіки, покладених чинним законодавством в основу формування мінімальної заробітної плати. Актуальність проблеми підсилюється тим фактором, що заробітна плата на сучасному етапі залишається для населення нашої країни головним джерелом доходів та підтримки життєвого рівня, оскільки оплата праці в сукупності доходів займає головне місце.

Заробітна плата $є$ не лише індикатором, що визначає загальний життєвий рівень працівників. Від іiі розміру, частки у валовому національному продукті багато в чому залежать також можливості розвитку економіки взагалі.

Важливим етапом дослідження виступає рейтингове оцінювання країн за основними показниками ринку праці, яке проводиться за допомогою розрахунку інтегральної оцінки на основі вище використаної системи статистичних показників, які розподілено на стимулятори (рівень зайнятості населення, середньомісячна заробітна плата) та дестимулятори (рівень безробіття) i розраховується на основі стандартизованих статистичних показників.

Отримані значення рейтингових оцінок коливаються в межах від 0 до 1, що дозволяє оцінити стан окремої країни стосовно до шкал виміру відносних відстаней. В таблиці представлено стандартизовані значення показників та рейтингову оцінку країн за основними показниками ринку праці за 3 квартал 2015 р. 
Рейтингова оцінка України та країн СС за основними показниками ринку праці у 3 кварталі 2015 р.

\begin{tabular}{|c|c|c|}
\hline Країна & Ранг країни & Рейтингова оцінка \\
\hline Німеччина & 1 & 0,916 \\
\hline Нідерланди & 2 & 0,888 \\
\hline Велика Британія & 3 & 0,861 \\
\hline Люксембург & 4 & 0,813 \\
\hline Естонія & 5 & 0,706 \\
\hline Бельгія & 6 & 0,680 \\
\hline Ірландія & 7 & 0,679 \\
\hline Франція & 8 & 0,670 \\
\hline Чеська Республіка & 9 & 0,652 \\
\hline Мальта & 10 & 0,635 \\
\hline Словенія & 11 & 0,614 \\
\hline Литва & 12 & 0,550 \\
\hline Латвія & 13 & 0,546 \\
\hline Угорщина & 14 & 0,541 \\
\hline Польща & 15 & 0,524 \\
\hline Румунія & 16 & 0,496 \\
\hline Португалія & 17 & 0,485 \\
\hline Болгарія & 18 & 0,479 \\
\hline Словаччина & 19 & 0,441 \\
\hline Україна & 20 & 0,332 \\
\hline Хорватія & 21 & 0,292 \\
\hline Іспанія & 22 & 0,273 \\
\hline
\end{tabular}

За рейтинговим оцінюванням ринку праці у 3 кварталі 2015 р. Україна посіла 20 місце серед 23 країн. Лише в Хорватії та Іспанії рейтингова оцінка за досліджуваним напрямом виявилась менше. В інших 19 країнах СС було більш ефективно використано власний трудовий потенціал.

Побудова рейтингової оцінки за основними показниками ринку праці викликана соціально-економічними умовами, в яких функціонують окремі країни. Представлені етапи рейтингового оцінювання розвитку країн за основними показниками ринку праці дозволяють всебічно дослідити соціально-трудові відносини в них. Крім того, для подальшого удосконалення процесів зайнятості в Україні, такий підхід дасть змогу визначити механізми його регулювання на рівні окремих територій з метою подолання структурних та територіальних диспропорцій.

Висновки. Політика інтеграції України до інституцій ЄС передбачає, в тому числі, й подальшу гармонізації національного законодавства у сфері сприяння зайнятості населення. Важливим орієнтиром розвитку українського ринку праці виступає система статистичних показників економічної 
активності населення, детальний аналіз яких та порівняння, на постійній основі, з аналогічними значеннями країн СС дозволить оцінювати основні тенденції руху та ефективність політики у сфері сприяння зайнятості в Україні. Ключову роль при реформуванні національного ринку праці слід приділити підвищенню соціально-економічних стандартів економічно активного населення.

Наукова новизна полягає у застосуванні методичних підходів щодо рейтингової оцінки України та країн $Є С$ за основними показниками зайнятості населення. Визначений ранг країн $є$ основою для визначення подібних українському ринків праці країн $Є С$, що дозволить використовувати позитивний досвід виокремлених країн для вдосконалення політики зайнятості в Україні.

Теоретичне і практичне значення полягає в проведенні комплексного порівняльного аналізу ринків праці України та країн $С$, результати якого можуть бути використані українськими органами державного управління при розробці стратегій щодо інтеграції до європейських інституцій.

Перспективи подальших наукових розробок можуть бути спрямовані на розширення та поглиблення аналітичних можливостей статистичного аналізу ринку праці окремої країни у порівнянні з міжнародними рівнем.

\section{Література:}

1. Офіційний сайт Верховної Ради України [Електронний ресурс]. - Режим доступу: http://portal.rada.gov.ua/rada/control/uk/index/;

2. Офіційний сайт Державної служби статистики [Електронний ресурс]. - Режим доступу: http://www.ukrstat.gov.ua/;

3. Офіційний сайт Євростату [Електронний ресурс]. - Режим доступу: http://epp.eurostat.ec.europa.eu/;

4. Ślusarczyk B. Unemployment as a regional problem // Aspect of security for the protection of the interests / M. Kelemen, A. Olak, V. Blažek, E. Bojar a kolektiv; Politechnika Lubelska Polska. - Lublin, 2014. - S. 296-322.

5. Ślusarczyk B. Sustainable development policies of the European Union as expressions of socio-economic security / B. Ślusarczyk, A. Wolak-Tuzimek // Bezpecnostne Forum 2014. Banska Bystrica: Univerzita Mateja Bela, 2014. - S. 344-350. 